\title{
Pengaruh Faktor Good Corporate Governance, Free Cash Flow, dan Leverage Terhadap Manajemen Laba
}

\author{
Dian Agustia \\ Fakultas Ekonomi Bisnis Universitas Airlangga Surabaya
}

\begin{abstract}
ABSTRAK
Penelitian ini bertujuan untuk memberikan bukti empiris pengaruh good corporate governance, free cash flow, dan rasio leverage terhadap manajemen laba. Good corporate governance diukur dengan ukuran komite audit, proporsi komite audit independen, kepemilikan institusional dan kepemilikan manajerial. Discretionary accrual digunakan sebagai proksi manajemen laba. Sampel penelitian adalah 14 perusahaan tekstil yang terdaftar di Bursa Efek Indonesia, yang dipilih menggunakan purposive sampling selama periode penelitian, tahun 2007-2011. Data dianalisis menggunakan regresi berganda. Berdasarkan hasil pengujian disimpulkan bahwa semua komponen good corporate governance (ukuran komite audit, proporsi komite audit independen, kepemilikan institusional dan kepemilikan manajerial) tidak berpengaruh signifikan terhadap manajemen laba, sedangkan leverage berpengaruh, free cash flow berpengaruh negative dan signifikan terhadap manajemen laba. Hal ini berarti perusahaan dengan free cash flow yang tinggi akan membatasi praktek manajemen laba.
\end{abstract}

Kata kunci: manajemn laba, good corporate governance, free cash flow, rasio leverage

\begin{abstract}
The aim of this research is to provide empirical evidence on the impact of good corporate governance, free cash flow, and leverage ratio on earnings management. Good corporate governance is measured by audit committee's size, the proportion of independent commissioners, institutional ownership, and managerial ownership. Discretionary accrual is the proxy of earning management. This research used 14 textile companies listed in Indonesia Stock Exchange, selected using purposive sampling method, during the research period 2007 2011. Data were analyzed using multiple regression method. Based on the result of analysis concluded that all components of good corporate governance (audit committee's size, the proportion of independent commissioners, institutional ownership, and managerial ownership), have no significant effect on earnings management, while leverage ratio has a significant effect on earnings management, and free cash flow has a negative and significant effect on earnings management. It means that companies with high free cash flow will restrict the practice of earnings management.
\end{abstract}

Keywords: Earnings management, good corporate governance, free cash flow, leverage ratio.

\section{PENDAHULUAN}

Laporan keuangan merupakan salah satu sumber informasi mengenai kondisi dan kinerja suatu perusahaan bagi pihak eksternal. Informasi tersebut menyangkut posisi keuangan, kinerja serta perubahan posisi keuangan suatu perusahaan, dan bermanfaat bagi sejumlah besar pemakai dalam pengambilan keputusan ekonomi. Salah satu elemen penting dalam laporan keuangan yang digunakan untuk mengukur kinerja manajemen adalah laba. Informasi laba merupakan perhatian utama untuk menaksir kinerja atau prestasi manajemen. Selain itu informasi laba juga digunakan oleh investor atau pihak lain yang berkepentingan sebagai indikator efisiensi penggunaan dana yg tertanam dalam perusahaan yang diwujudkan dalam tingkat pengembalian dan indikator untuk kenaikan kemakmuran (Ghozali dan Chariri, 2007:350). 
Adanya asimetri informasi dan kecenderungan dari pihak eksternal (investor) untuk lebih memperhatikan informasi laba sebagai parameter kinerja perusahaan, akan mendorong manajemen untuk melakukan manipulasi dalam menunjukkan informasi laba, yang disebut sebagai manajemen laba (earnings management). Beberapa faktor yang dapat mempengaruhi praktek manajemen laba dalam perusahaan adalah praktek good corporate governance, kebijakan free cash flow dan leverage ratio. Ada ketidak konsistenan hasil penelitian faktor-faktor tersebut dalam mempengaruhi praktek manajemen laba perusahaan.

Berdasarkan beberapa teori yang mengindikasikan free cash flow sebagai salah satu faktor yang dapat mempengaruhi adanya praktik manajemen laba serta pentingnya penerapan good corporate governance dan peranan auditor dalam meminimalisasi dan mendeteksi manajemen laba. Manajemen laba bisa menjadi salah satu faktor yang dapat mengurangi kredibilitas laporan keuangan karena angka yang dilaporkan tersebut tidak mencerminkan kondisi sebenarnya. Perilaku manajer yang melakukan manajemen laba dapat diminimalisir dengan menerapkan good corporate governance. Dalam studi Kouki et al. (2011), Pradipta (2011), Oktovianti dan Agustia (2012), dan Dewanto (2012) menggunakan empat komponen dalam mengidentifikasi good corporate governance yaitu komite audit, dewan komisaris independen, kepemilikan institusional, dan kepemilikan manajerial. Pradipta (2011) yang menyatakan bahwa komite audit, kepemilikan institusional dan manjerial tidak memiliki pengaruh terhadap praktik manajemen laba. GCG dapat mengurangi konflik keagenan dan meningkatkan pengungkapan yang dapat membatasi asimetri informasi.

Manajemen laba menurut Scott (2011:423) adalah "the choice by a manager of accounting policies so as to achieve some specific objective". Hal ini berarti manajemen laba merupakan keputusan dari manajer untuk memilih kebijakan akuntansi tertentu yang dianggap bisa mencapai tujuan yang diinginkan, baik itu untuk meningkatkan laba atau mengurangi tingkat kerugian yang dilaporkan. Menurut Scott (2011:426) beberapa motivasi yang mendorong manajemen melakukan earning management, antara lain adalah (1) Motivasi bonus, yaitu manajer akan berusaha mengatur laba bersih agar dapat memaksimalkan bonusnya; (2) Hipotesis perjanjian hutang (Debt Covenant Hypothesis), berkaitan dengan persyaratan perjanjian hutang yang harus dipenuhi, laba yang tinggi diharapkan dapat mengurangi kemungkinan terjadinya pelanggaran syarat perjanjian hutang; (3) Meet Investors Earnings Expectations and Maintain Reputation, perusahaan yang melaporkan laba lebih besar daripada ekspektasi investor harga sahamnya akan mengalami peningkatan yang signifikan karena investor memprediksi perusahaan akan mempunyai masa depan yang lebih baik; (4) IPO (Initial Public Offering), manajer perusahaan yang akan go public termotivasi untuk melakukan manajemen laba sehingga laba yang dilaporkan menjadi tinggi dengan harapan dapat menaikkan harga saham perusahaan.

Perusahaan dengan arus kas bebas (free cash flow) yang tinggi akan memiliki kesempatan yang lebih besar untuk melakukan manajemen laba, karena perusahaan tersebut terindikasi menghadapi masalah keagenan yang lebih besar (Chung et al., 2005). Penelitian sebelumnya menunjukkan bahwa perusahaan dengan surplus arus kas bebas yang tinggi juga cenderung melakukan praktik manajemen laba dengan meningkatkan laba yang dilaporkan untuk menutupi tindakan pihak manajer yang tidak optimal dalam memanfaatkan kekayaan perusahaan. White et al. (2003:68) mengungkapkan bahwa semakin besar free cash flow yang tersedia dalam suatu perusahaan, maka semakin sehat perusahaan tersebut karena memiliki kas yang tersedia untuk pertumbuhan, pembayaran hutang, dan deviden. Free cash flow merupakan determinan penting dalam penentuan nilai perusahaan, sehingga manajer perusahaan lebih terfokus pada usaha untuk meningkatkan free cash flow (Sawir, 2004: 94).

Investor untuk melihat kemampuan dan resiko perusahaan, salah satunya dengan leverage rasio. Penggunaan debt to asset ratio sebagai proksi variabel leverage ratio. Perusahaan yang memiliki rasio hutang relatif tinggi akan memiliki ekspektasi pengembalian yang juga lebih tinggi ketika perekonomian berada pada kondisi yang normal, namun memiliki resiko kerugian ketika ekonomi mengalami resesi (Brigham dan Houston, 2010:143). Dengan memperoleh dana melalui hutang, para pemegang saham dapat mempertahankan kendali mereka atas perusahaan tersebut dengan sekaligus membatasi investasi yang mereka tanamkan.

Berdasarkan latar belakang di atas maka rumusan masalah dalam penelitian ini adalah: Apakah ukuran komite, audit proporsi dewan komisaris, independen kepemilikan institusional, kepemilikan manajerial, free cash flow dan leverage ratio berpengaruh terhadap manajemen laba?

Tujuan penelitian ini adalah untuk memperoleh bukti empiris pengaruh ukuran komite, audit proporsi dewan komisaris, independen kepemilik- 
an institusional, kepemilikan manajerial, free cash flow dan leverage ratio terhadap manajemen laba.

Hasil penelitian ini diharapkan dapat memberikan informasi yang bermanfaat untuk meningkatkan penerapan good corporate governance free cash flow, dan leverage dalam rangka pengelolaan perusahaan, terutama yang terkait dengan usaha meminimalkan praktik manajemen laba.

\section{Teori Keagenan}

Dalam rangka memahami corporate governance maka digunakanlah dasar perspektif hubungan keagenan. Jensen dan Meckling (1976) menyatakan bahwa hubungan keagenan adalah sebuah kontrak antara manajer (agent) dengan investor (principal). Terjadinya konflik kepentingan antara pemilik dan agen karena kemungkinan agen bertindak tidak sesuai dengan kepentingan principal, sehingga memicu biaya keagenan (agency cost). Eisenhardt (1989) menggunakan tiga asumsi sifat dasar manusia guna menjelaskan tentang teori agensi yaitu (1) manusia pada umumnya mementingkan diri sendiri (self interest), (2) manusia memiliki daya pikir terbatas mengenai persepsi masa mendatang (bounded rationality), dan (3) manusia selalu meng-hindari resiko (risk averse). Berdasarkan asumsi sifat dasar manusia tersebut manajer sebagai manusia kemungkinan besar akan bertindak berdasarkan sifat opportunistic, yaitu mengutamakan kepentingan pribadinya. Selain itu corporate governance juga berkaitan dengan bagaimana para investor mengontrol para manajer (Shleifer dan Vishny, 1997). Dengan kata lain yakni corporate governance diharapkan akan dapat berfungsi untuk menekan atau menurunkan biaya keagenan (agency cost).

\section{GoodCorporate governance}

Tata kelola perusahaan mencakup hubungan antara para pemangku kepentingan (stakeholder) yang terlibat serta tujuan pengelolaan perusahaan. Pihak-pihak utama dalam tata kelola perusahaan adalah pemegang saham, manajemen, dan dewan direksi. Pemangku kepentingan lainnya termasuk karyawan, pemasok, pelanggan, bank dan kreditor lain, regulator, lingkungan, serta masyarakat. Menurut Komite Cadbury (1992), corporate governance merupakan suatu sistem yang mengarahkan dan mengendalikan perusahaan dengan tujuan agar mencapai kesinambungan antara kekuatan kewenangan yang diperlukan oleh perusahaan untuk menjamin kelangsungan eksistensinya dan pertanggung- jawaban kepada stakeholder (Surya dan Yustivandana, 2008:24).

Kepemilikan managerial adalah kepemilikan saham perusahaan oleh managerial. Kepemilikan managerial merupakan alat monitoring internal yang penting untuk memecahkan konflik agensi antara external stockholders dan manajemen (Chen dan Steiner, 1999). Fungsi dewan komisaris sesuai dengan yang dinyatakan dalam National Code for Good Corporate governance (2001) adalah memastikan bahwa perusahaan telah melakukan tanggung jawab sosial dan mempertimbangkan kepentingan berbagai stakeholder perusahaan sebaik memonitor efektifitas pelaksanaan good corporate governance. Pengaruh ukuran dewan komisaris terhadap kinerja perusahaan memiliki hasil yang beragam. Salah satu argumen menyatakan bahwa makin banyaknya personel yang menjadi dewan komisaris dapat berakibat pada makin buruknya kinerja yang dimiliki perusahaan (Yermack 1996, Eisenberg et al. 1998). Sesuai dengan Kep. 29/PM/2004, komite audit adalah komite yang dibentuk oleh dewan komisaris untuk melakukan tugas pengawasan pengelolaan perusahaan. Keberadaan komite audit sangat penting bagi pengelolaan perusahaan. Weston dan Brigham (1994:17-23) menyatakan bahwa potensi munculnya konflik dalam hubungan agensi sangat besar, yaitu ketika manajemen perusahaan memiliki kurang dari 100\% saham biasa milik perusahaan maka potensi konflik itupun muncul. Konflik terjadi karena adanya keinginan agen untuk mendapatkan gaji yang tinggi atau mendapatkan fasilitas tertentu yang sama dengan milik principal demi kenyamanan pribadinya. Jensen dan Meckling (1976) menemukan bahwa kepemilikan manajerial berhasil menjadi salah satu faktor penentu untuk mengurangi masalah keagenan dari manajer dengan menyelaraskan kepentingan-kepentingan manajer dengan pemegang saham.

Secara umum dewan komisaris ditugaskan dan diberi tanggung jawab atas pengawasan kualitas informasi yang terkandung dalam laporan keuangan. Hal ini penting mengingat adanya kepentingan dari manajemen untuk melakukan earnings management yang berdampak pada berkurangnya kepercayaan investor. Untuk mengatasinya dewan komisaris diperbolehkan untuk memiliki akses pada informasi perusahaan. Dewan komisaris tidak memiliki otoritas dalam perusahaan, maka dewan direksi bertanggung jawab untuk menyampaikan informasi terkait dengan perusahaan kepada dewan komisaris (NCCG, 2001). Selain mensupervisi dan memberi nasihat pada dewan direksi sesuai dengan UU No. 1 tahun 1995, fungsi dewan komisaris yang lain 
sesuai dengan yang dinyatakan dalam National Code for Good Corporate governance (2001) adalah memastikan bahwa perusahaan telah melakukan tanggung jawab sosial dan mempertimbangkan kepentingan berbagai stakeholder perusahaan sebaik memonitor efektifitas pelaksanaan good corporate governance.

Pengaruh ukuran dewan komisaris terhadap kinerja perusahaan memiliki hasil yang beragam. Salah satu argumen menyatakan bahwa makin banyaknya personel yang menjadi dewan komisaris dapat berakibat pada makin buruknya kinerja yang dimiliki perusahaan (Yermack 1996, Eisenberg et al. 1998, dan Jensen 1993). UU Nomor 40 Tahun 2007 tentang Perseroan Terbatas, mengatakan bahwa jumlah anggota dewan komisaris terdiri dari lebih satu orang anggota merupakan majelis dan setiap anggota Dewan Komisaris tidak dapat bertindak sendiri-sendiri, melainkan berdasarkan keputusan Dewan Komisaris. Yu (2006) dan Cornett et al. (2009) menemukan bahwa ukuran dewan komisaris berpengaruh negatif secara signifikan terhadap earnings management yang diukur dengan menggunakan Modified Jones Model untuk memperoleh nilai akrual kelolaannya.

\section{Leverage Ratio}

Rasio leverage menggambarkan sumber dana operasi yang digunakan oleh perusahaan. Rasio leverage juga menunjukkan risiko yang dihadapi perusahaan. Semakin besar risiko yang dihadapi oleh perusahaan maka ketidakpastian untuk menghasilkan laba di masa depan juga akan makin meningkat. Foster (1986:65) mengungkapkan bahwa terdapat hubungan antara rasio leverage dengan return perusahaan. Artinya hutang dapat digunakan untuk memprediksi keuntungan yang kemungkinan bisa diperoleh bagi investor jika berinvestasi pada suatu perusahaan.

Jensen and Meckling (1976) berargumen tentang moral hazard untuk menjelaskan agency cost of debt, bahwa level hutang tinggi akan menyebabkan perusahaan untuk memilih pada proyek-proyek investasi berisiko secara berlebihan. Masalah kerugian juga dapat memberikan kontribusi atas kebijakan pendanaan melalui hutang. Myers and Majluf (1984) menyatakan bahwa jika manajer-manajer mempunyai informasi privat mengenai proyek-proyek investasinya, mereka berharap memperoleh pendanaan dari pihak luar untuk mengganti investor atas kemungkinan menemukan perusahaan yang kinerjanya buruk pada proyek-proyek yang mempunyai net present value negatif. DeAngelo et al. (1994) dan Fraser dan Ormiston (2004 : 185) mengukur leverage ratio dengan persamaan berikut:

$$
\text { Leverage ratio }=\frac{\text { Net Liabilitie s }}{\text { Total Assets }}
$$

\section{Ukuran Perusahaan}

Ukuran perusahaan akan mempengaruhi struktur pendanaan perusahaan. Perusahaan cenderung akan memerlukan dana yang lebih besar dibandingkan perusahaan yang lebih kecil. Tambahan dana tersebut bisa diperoleh dari penerbitan saham baru atau penambahan hutang. Motivasi untuk mendapatkan dana tersebut akan mendorong pihak manajemen untuk melakukan praktik manajemen laba, sehingga dengan pelaporan laba yang tinggi maka calon investor maupun kreditur akan tertarik untuk menanamkan dananya.

Berdasarkan size hypothesis yang dipaparkan oleh Watt dan Zimmerman (1986) berasumsi bahwa perusahaan besar secara politis, lebih besar melakukan transfer political cost dalam kerangka politic process, dibandingkan dengan perusahaan kecil. Lebih lanjut beberapa peneliti berhasil membuktikan bahwa political process memiliki dampak pada pemilihan prosedur akuntansi oleh perusahaan yang berukuran besar (Naz et al., 2011). Ukuran perusahaan dalam penelitian ini menggunakan proksi log natural dari total asset. Total aset digunakan sebagai proksi ukuran perusahaan dengan pertimbangan total aset perusahaan relatif lebih stabil dibandingkan dengan jumlah penjualan dan nilai kapitalisasi pasar (Guna dan Herawaty, 2010).

\section{Manajemen Laba}

Menejemen Laba merupakan suatu tindakan manajer yang memilih kebijakan akuntansi untuk mencapai beberapa tujuan yang spesifik dan kebijakan akuntansi yang dimaksud adalah penggunaan accrual dalam menyusun laporan keuangan (Scott, 2006:344).

Dalam berbagai penelitian pengukuran discretionary accruallabnormal accrual diukur untuk mendeteksi pola perilaku earnings management. Penelitian Jones (1991) yang meneliti praktik earnings management selama import investigations. Jones mengidentifikasikan earnings management dengan mengukur discretionary accrual dan dinyatakan bila emiten melakukan earnings management dengan pola income increasing akan memiliki nilai discretionary accrual yang positif dan jika melakukan income decreasing (discretionnary accrual negatif) untuk mendapatkan proteksi import dari pemerintah. 


\section{Pengembangan Hipotesis}

Pengaruh Ukuran Komite Audit Terhadap Manajemen Laba

Komite audit adalah pihak yang bertanggung jawab melakukan pengawasan dan pengendalian untuk menciptakan keadilan, transparansi, akuntabilitas, dan responsibilitas. Keempat faktor inilah yang membuat laporan keuangan menjadi lebih berkualitas (Sulistyanto, 2008:156).

Hasil penelitian oleh Lin et al. (2006) dan Alves (2011) juga mengungkapkan kesimpulan yang sama, yaitu keberadaan komite audit di perusahaan terbukti berpengaruh negatif terhadap praktik manajemen laba. Namun hasil penelitian itu berbeda dengan Alkdaei dan Hanefah (2012) yaitu bahwa besar kecilnya ukuran komite audit terbukti tidak berpengaruh terhadap manajemen laba. Hal ini terjadi karena tujuan perusahaan membentuk komite audit hanya sekedar untuk memenuhi peraturan Bapepam yang bersifat mandatory. Berdasarkan uraian tersebut, dalam penelitian ini diajukan hipotesis sebagai berikut:

H1a: Ukuran komite audit berpengaruh terhadap manajemen laba.

Pengaruh Proporsi Dewan Komisaris Independen Terhadap Manajemen Laba

Dewan komisaris independen antara lain bertugas dan bertanggung jawab untuk memastikan bahwa perusahaan memiliki strategi bisnis yang efektif (memantau jadwal, anggaran, dan efektivitas strategi), mematuhi hukum dan perundangan yang berlaku, serta menjamin bahwa prinsip-prinsip dan praktik good corporate governance telah dipatuhi dan diterapkan dengan baik (Sulistyanto, 2008:144).

Hasil penelitian Yu (2006), Murhadi (2009), Oktovianti dan Agustia (2012). yang menunjukkan bahwa proporsi atau ukuran dewan komisaris independen tidak berpengaruh terhadap manajemen laba. Tetapi, menurut Kouki et al. (2011) yang melakukan penelitian dengan mengambil sampel dari setiap sektor industri menghasilkan kesimpulan bahwa komisaris independen berpengaruh negatif terhadap praktik manajemen laba, kesimpulan ini diperkuat dengan penelitian oleh Dewanto (2012:75) yang juga memperoleh hasil bahwa proporsi dewan komisaris independen terbukti berpengaruh negatif terhadap praktik manajemen laba. Berdasarkan uraian tersebut, dalam penelitian ini diajukan hipotesis sebagai berikut:
H1b: Proporsi dewan komisaris independen berpengaruh terhadap manajemen laba.

Pengaruh Kepemilikan Institusional Terhadap Manajemen Laba

Kepemilikan institusional adalah bagian dari saham perusahaaan yang dimiliki oleh investor institusi, seperti perusahaan asuransi, institusi keuangan (bank, perusahaan keuangan, kredit), dana pensiun, investment banking, dan perusahaan lainnya yang terkait dengan kategori tersebut (Yang et al., 2009). Chew dan Gillan (2009:176) menjelaskan bahwa terdapat dua jenis investor institusional, yaitu investor institusional sebagai transient investors (pemilik sementara perusahaan) dan investor institusional sebagai sophisticated investors. Kepemilikan institusional mempunyai pengaruh yang negatif terhadap praktik manajemen laba, semakin kecil persentase kepemilikan institusional maka semakin besar pula kecenderungan pihak manajer dalam mengambil kebijakan akuntansi tertentu untuk memanipulasi pelaporan laba (Widyastuti, 2009). Hasil tersebut berbeda dengan hasil penelitian oleh Guna dan Herawaty (2010) dan Yang et al. (2009), Oktovianti dan Agustia (2012), yang menghasilkan kesimpulan bahwa variabel kepemilikan institusional tidak berpengaruh terhadap manajemen laba karena investor institusional sebagai pemilik sementara perusahaan lebih terfokus pada current earnings. Berdasarkan uraian tersebut, dalam penelitian ini diajukan hipotesis sebagai berikut:

H1c: Kepemilikan institusional berpengaruh terhadap manajemen laba.

Pengaruh Kepemilikan Manajerial Terhadap Manajemen Laba

Penelitian sebelumya mengungkapkan bahwa kepemilikan manajerial berpengaruh negatif terhadap manajemen laba dan bisa meningkatkan kualitas dari proses pelaporan keuangan, hal ini dikarenakan ketika manajer juga memiliki porsi kepemilikan, maka mereka akan bertindak sama seperti pemegang saham umumnya dan memastikan bahwa laporan keuangan telah disajikan dengan wajar dan mengungkapkan kondisi riil perusahaan (Kouki et al., 2011). Yang et al. (2008) yang menyebutkan praktik manajemen laba di perusahaan cenderung akan mengalami penurunan seiring dengan peningkatan jumlah saham yang dimiliki oleh pihak manajemen perusahaan.

Hasil penelitian Guna dan Herawaty (2010) dan Pradipta (2011) adalah kepemilikan manajerial tidak mempunyai pengaruh terhadap mana- 
jemen laba. Hasil penelitian Oktovianti dan Agustia (2012), yang menyatakan bahwa kepemilikan manajerial ini berpengaruh negatif signifikan terhadap earnings management.

Berdasarkan uraian tersebut, dalam penelitian ini diajukan hipotesis sebagai berikut:

H1d: Kepemilikan manajerial berpengaruh terhadap manajemen laba.

\section{Pengaruh Free Cash Flow Terhadap Mana- jemen Laba}

White et al. (2003:68) mengungkapkan bahwa semakin besar free cash flow yang tersedia dalam suatu perusahaan, maka semakin sehat perusahaan tersebut karena memiliki kas yang tersedia untuk pertumbuhan, pembayaran hutang, dan deviden. Hal ini juga dapat diartikan bahwa semakin kecil nilai FCF yang dimiliki perusahaan, maka perusahaan tersebut bisa dikategorikan semakin tidak sehat.

Hasil penelitian oleh Isnawati (2011) yang menyatakan bahwa FCF berpengaruh negatif signifikan terhadap manajemen laba, sedangkan Kangarluei et al. (2011) memberikan bukti lain bahwa besar kecilnya nilai FCF suatu perusahaan tidak mempunyai pengaruh secara signifikan terhadap kemungkinan terjadinya manajemen laba. Berdasarkan uraian tersebut, dalam penelitian ini diajukan hipotesis sebagai berikut:

H2: Free cash flow berpengaruh terhadap manajemen laba.

\section{Pengaruh Leverage Ratio Terhadap Mana- jemen Laba}

Leverage adalah perbandingan antara total kewajiban dengan total aset perusahaan. Rasio ini menunjukkan besarnya besar aset yang dimiliki perusahaan yang dibiayai dengan hutang. Hasil penelitian Mamedova (2008) dan Oktovianti dan Agustia (2012) yang menyatakan bahwa leverage perusahaan berpengaruh terhadap praktek manajemen melakukan earnings management. Dalam teori keagenan, semakin dekat perusahaan dengan pelanggaran perjanjian utang yang berbasis akuntansi, lebih memungkinkan manajer perusahaan untuk memilih prosedur akuntansi yang memindahkan laba yang dilaporkan dari periode masa datang ke periode saat ini (Watts and Zimmerman, 1986). Berdasarkan uraian tersebut, maka hipotesis yang diajukan sebagai berikut:

H3: Leverage ratio berpengaruh terhadap manajemen laba.

\section{Kerangka Berfikir}

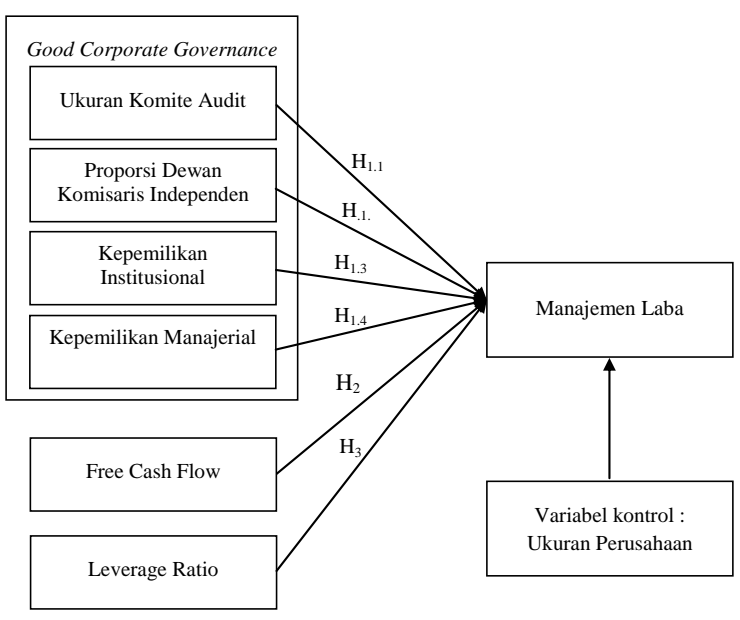

\section{METODE PENELITIAN}

\section{Rancangan Penelitian}

Jenis penelitian ini merupakan basic research (penelitian dasar) dengan pendekatan kuantitatif yaitu penelitian dengan menggunakan hipotesis dengan menggunakan alat uji statistik untuk menyimpulkan hipotesis yang menggunakan pengujian kausal (causal hypothesis). Hipotesis penjelas (explanatory hypothesis) atau hipotesis kausal (causal hypothesis) adalah hipotesis yang menyatakan hubungan satu variabel yang menyebabkan perubahan variabel lain (Sekaran, 2007).

\section{Identifikasi Variabel dan Definisi Operasio- nal}

Pada penelitian ini terdapat variabel bebas, variabel kontrol dan variabel terikat. Variabel bebas pada penelitian ini adalah Ukuran Komite Audit, Proporsi Dewan Komisaris Independen, Kepemilikan Institusional, Kepemilikan Manajerial, Free Cash Flow dan Leverage Ratio. Variabel kontrol dalam penelitian ini adalah ukuran perusahaan. Variabel terikat dalam penelitian ini adalah manajemen laba.

Definisi operasional diperlukan agar konsep yang digunakan dapat diukur secara empiris serta menghindari terjadinya kesalahpahaman dalam penafsiran yang berbeda. Defini operasional dalam penelitian ini adalah sebagai berikut:

\section{Ukuran Komite Audit}

Ukuran komite audit didefinisikan sebagai keberadaan komite audit yang dimiliki oleh suatu perusahaan. Variabel komite audit dalam peneliti- 
an ini diukur dengan menggunakan jumlah anggota komite audit yang ada di perusahaan. Berdasarkan peraturan Bapepam No IX.I.5 dijelaskan bahwa keberadaan komite audit sekurang-kurangnya terdiri dari 3 orang dimana komisaris independen perusahaan menjadi ketua komite, sedangkan yang lain adalah pihak ekstern yang independen dan minimal salah seorang diantaranya memiliki kemampuan di bidang akuntansi dan keuangan.

\section{Proporsi Dewan Komisaris Independen}

Peran dewan komisaris adalah memonitor kebijakan direksi yang diharapkan dapat meminimalisir permasalahan agensi yang muncul antara dewan direksi dan pemengang saham. Jumlah komisaris independen wajib mewakili sedikitnya $30 \%$ dari jumlah Komisaris dalam Dewan Komisaris (Peraturan BAPEPAM-LK No. IX.I.5). Proporsi dewan komisaris independen dihitung dengan menggunakan persentase dari komisaris independen dibandingkan dengan total jumlah komisaris.

\section{$\underline{\text { Kepemilikan Institusional }}$}

Kepemilikan institusional merupakan kepemilikan saham perusahaan oleh investor besar seperti perusahaan asuransi, bank, dana pensiun, dan investment banking yang membeli saham perusahaan dalam jumlah besar (Griffin dan Ebert, 2007:115). Kepemilikan institusional diukur dengan jumlah saham yang dimiliki oleh investor institusional dibandingkan dengan total saham perusahaan.

\section{$\underline{\text { Kepemilikan Manajerial }}$}

Kepemilikan manajemen adalah saham yang dimiliki oleh manajemen secara pribadi maupun saham yang dimiliki oleh anak cabang perusahaan bersangkutan beserta afiliasinya. Indikator untuk mengukur kepemilikan manajerial adalah presentase perbandingan jumlah saham yang dimiliki pihak manajemen dengan seluruh modal saham perusahaan yang beredar.

\section{Free Cash Flow}

Free Cash Flow merupakan arus kas aktual yang didistribusikan kepada investor sesudah perusahaan melakukan semua investasi dan modal kerja yang diperlukan untuk menjaga kelangsungan operasionalnya. Variabel ini dihitung dengan menggunakan rumus Brigham dan Houston (2010:67), yaitu:
Free Cash Flow $=$ NOPAT - investasi bersih pada modal operasi

Keterangan:

NOPAT (net operating profit after tax) = EBIT $(1-$ tarif pajak)

Investasi bersih modal operasi $=$ Total modal operasit - total modal operasit-1

Total modal operasi $=$ Modal kerja operasi bersih + aset tetap bersih

Modal kerja operasi bersih $=$ Aset lancar - kewa jiban lancar tanpa bunga

Free cash flow dalam penelitian ini diukur dengan menggunakan skala rasio, dimana nilai free cash flow dibagi dengan total asset pada periode yang sama dengan tujuan agar lebih comparable bagi perusahaan-perusahaan yang dijadikan sampel (Kangarluei et al., 2011).

\section{Leverage Ratio}

Variabel leverage menggunakan rasio Debt to Asset, yaitu perbandingan total kewajiban (hutang jangka pendek dan hutang jangka panjang) dengan total aset yang dimiliki perusahaan pada akhir tahun (Gibson, 2001:241). Rumus leverage ratio adalah:

$$
\text { Leverage ratio }=\frac{\text { Total Hutang }}{\text { Total Aset }}
$$

\section{$\underline{\text { Manajemen Laba }}$}

Manajemen Laba merupakan suatu tindakan manajer yang memilih kebijakan akuntansi untuk mencapai beberapa tujuan yang spesifik dan kebijakan akuntansi yang dimaksud adalah penggunaan accrual dalam menyusun laporan keuangan . Earning Management dalam penelitian ini diukur dengan meng-identifikasi/mengukur discretionary accrual dengan menggunakan Modified Jones Model (Dechow et al., 1996). Discretionary accruals dihitung dengan menggunakan rumus sebagai berikut:

$$
\mathrm{TACit}_{\mathrm{it}}=\mathrm{N}_{\mathrm{it}}-\mathrm{CFO}_{\mathrm{it}}
$$

Nilai total accrual (TA) diestimasi dengan persamaan regresi linear berganda yang berbasis ordinary least square (OLS) sebagai berikut: $\mathrm{TAC}_{\mathrm{it}} / \mathrm{A}_{\mathrm{it}-1}=B_{1}\left(1 / \mathrm{A}_{\mathrm{it}-1}\right)+B_{2}\left(\Delta \mathrm{REV}_{\mathrm{t}} / \mathrm{A}_{\mathrm{it}-1}\right)+B_{3}\left(\mathrm{PPE}_{\mathrm{t}}\right.$

$$
\left./ \mathrm{A}_{\mathrm{it}-1}\right)+\mathrm{e}
$$

Dengan menggunakan koefisien regresi di atas nilai non discretionary accruals (NDA) dapat dihitung dengan rumus:

$$
\begin{aligned}
\mathrm{NDA}_{i t}= & B_{1}\left(1 / \mathrm{A}_{\mathrm{it}-1}\right)+B_{2}\left(\Delta \mathrm{REV}_{\mathrm{t}} / \mathrm{A}_{\mathrm{it}-1}-\Delta \mathrm{REC} t / \mathrm{A}_{\mathrm{it}-1}\right) \\
& +B_{3}\left(\mathrm{PPE}_{\mathrm{t}} / \mathrm{A}_{\mathrm{it}-1}\right)
\end{aligned}
$$


Selanjutnya discretionary accrual (DA) dapat dihitung sebagai berikut:

Keterangan:

$$
\mathrm{DA}_{\mathrm{it}}=\mathrm{TA}_{\mathrm{it}} / \mathrm{A}_{\mathrm{it}-1}-\mathrm{NDA}_{\mathrm{it}}
$$

$\mathrm{TAC}_{\mathrm{it}}=$ Total accruals perusahaan $\mathrm{i}$ pada periode $\mathrm{t}$

$\mathrm{N}_{\mathrm{it}} \quad=$ Laba bersih perusahaan $\mathrm{i}$ pada periode $\mathrm{t}$

$\mathrm{CFO}_{\text {it }}=$ Aliran kas dari aktivitas operasi perusahaan i pada periode $t$

$\mathrm{A}_{\mathrm{it}-1}=$ Total aset perusahaan $\mathrm{i}$ pada tahun $\mathrm{t}-1$

$\triangle \mathrm{REV}_{\mathrm{t}}=$ Perubahan pendapatan perusahaan $\mathrm{i}$ dari tahun $\mathrm{t}-1$ ke tahun $\mathrm{t}$

$\Delta \mathrm{REC}_{\mathrm{t}}=$ Perubahan piutang perusahaan $\mathrm{i}$ dari tahun $\mathrm{t}-1$ ke tahun $\mathrm{t}$

PPEt = Aset tetap (property, plant and equipment) perusahaan tahun $\mathrm{t}$

DA $_{\text {it }}=$ Discretionary Accruals perusahaan $\mathrm{i}$ pada periode ke $\mathrm{t}$

NDA $_{\text {it }}=$ Non Discretionary Accruals perusahaan i pada periode ke $\mathrm{t}$

$B_{1}, B_{2}, B_{3}=$ Koefisien regresi

$\mathrm{e} \quad=$ error

\section{Jenis dan Sumber Data}

Jenis data yang digunakan dalam penelitian ini adalah data sekunder berupa laporan keuangan 2007-2011. Data-data tersebut diperoleh dari situs BEI yaitu www.idx.co.id, dan ICMD 2006-2011.

\section{Populasi dan Sampel}

Populasi yang digunakan dalam penelitian ini adalah semua perusahaan Textil yang terdaftar di Bursa Efek Indonesia (BEI) yang berjumlah 18 perusahaan. Berdasarkan indeks produksi industri Besar dan sedang menurut Dua Digit Kode ISIC, perusahaan-perusahaan Tekstil mengalami naik turun pertumbuhan yang signifikan pada tahun 2007-2011. Dari tahun 2007 sampai 2009 mengalami penurunan signifikan, yaitu pada tahun 2007 sebesar 11,17, tahun 2008 sebesar 3,38, dan tahun 2009 menurun menjadi -5,41. Namun pada tahun 2010-2011, perusahaan-perusahaan tekstil mampu tumbuh kembali secara signifikan, yaitu pada tahun 2010 pertumbuhan meningkat menjadi 0.07 dan pada tahun 2011 menjadi 8,12. (Badan Pusat Statistik, 2011) Perusahaan yang menjadi sampel dalam penelitian ini dipilih dengan teknik purposive sampling. Kriteriakriteria dalam menentukan sampel yaitu sebagai berikut:

1. Perusahaan Textil yang menjadi sampel adalah perusahaan yang go publik dan masih terdaftar sebagai emiten pada BEI sampai tanggal 31 Desember 2011.
2. Data laporan keuangan perusahaan dan data untuk perhitungan variabel tersedia secara lengkap untuk tahun pelaporan dari 2006 sampai 2011.

3. Perusahaan menerbitkan laporan keuangan dengan tahun buku yang berakhir tanggal 31 Desember

4. Perusahaan menerbitkan laporan keuangan dalam satuan mata uang rupiah.

Sesuai dengan kriteria sampel yang telah ditetapkan, maka jumlah sampel dalam penelitian ini adalah sebanyak 14 perusahaan, dengan periode pengamatan 5 (lima) tahun berturut-turut dari tahun 2007-2011.

Tabel 1. Pemilihan Sampel Subjek Penelitian

\begin{tabular}{lc}
\hline \multicolumn{1}{c}{ Keterangan } & Jumlah \\
\hline $\begin{array}{l}\text { Perusahaan Textil yang terdaftar di BEI dan } \\
\text { masih tercatat sebagai emiten sampai 31 }\end{array}$ & 18 \\
$\begin{array}{l}\text { Desember 2011 } \\
\text { Perusahaan Textil yang tidak }\end{array}$ & \\
mempublikasikan laporan keuangan secara & \\
lengkap pada periode 2007-2011 dan tidak & \\
mempunyai data yang lengkap untuk & \\
perhitungan variabel penelitian & (1) \\
$\begin{array}{l}\text { Perusahaan yang tidak menerbitkan laporan } \\
\text { keuangan dalam satuan mata uang rupiah }\end{array}$ & (3) \\
Jumlah perusahaan yang dijadikan sampel & 14 \\
\hline
\end{tabular}

Sumber: data dari www.idx.co.id yang telah diolah

\section{Tehnik Analisis}

Penelitian ini menguji pengaruh beberapa variabel yaitu ukuran komite audit (UKA), proporsi dewan komisaris independen (DK), kepemilikan institusional (KI), kepemilikan manajerial (KM), free cash flow (FCF), dan leverage rasio, terhadap praktik manajemen laba (DA). Variabel kontrol adalah ukuran perusahaan. Pengujian terhadap rumusan menggunakan metode analisis regresi berganda (multiple regression analysis) yang terdapat dalam program SPSS (Statistical Program for Social Science) versi 18.0. Tahap pertama adalah uji asumsi klasik untuk membuktikan bahwa model yang digunakan adalah normal dan tidak mengandung gejala multikolinearitas, autokorelasi, dan heteroskedastisitas. Kemudian, dilakukan uji untuk melihat pengaruh variabel independen terhadap variabel dependen.

\section{Model Analisis}

Model yang digunakan dalam penelitian ini adalah analisis regresi berganda (multiple regres- 
sion analysis). Model regresi yang dikembangkan untuk menguji hipotesis-hipotesis dirumuskan adalah:

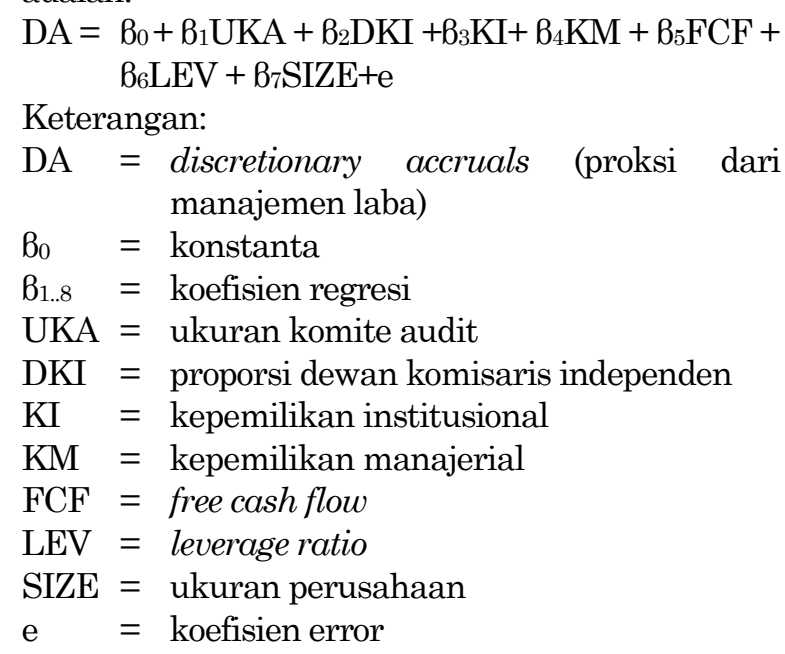

\section{HASIL PENELITIAN DAN PEMBAHASAN}

\section{Deskripsi Hasil Penelitian}

Perusahaan yang menjadi subjek dalam penelitian ini adalah perusahaan dari sektor industri Tektil yang terdaftar di Bursa Efek Indonesia pada periode 2007-2011yaitu sebanyak 18 perusahaan. Berdasarkan kriteria sampel, maka terdapat 14 perusahaan tektil yang go public dan tercatat sampai 31 Desember 2011.

Dalam penelitian ini variabel yang digunakan adalah manajemen laba (DA) sebagai variabel dependen, dan variabel independen yang meliputi ukuran komite audit (UKA), proporsi dewan komisaris independen (DKI), kepemilikan institusional (KI), kepemilikan manajerial (KM), dan free cash flow (FCF), serta leverage ratio (LEV). Variabel kontrol yakni ukuran perusahaan (SIZE).

Variabel praktik manajemen laba (DA) memiliki nilai minimum -1.0899 dan nilai maksimum 1.0750 serta rata-rata sebesar -0.011597. Standar deviasi 0.2431031 yang melebihi nilai rata-rata discretionary accruals menunjukkan tingginya fluktuasi data variabel DA selama periode pengamatan.

Variabel ukuran komite audit (UKA) memiliki nilai minimum 2.0 dan maksimum 4.0, yang berarti bahwa selama tahun 2007-2011 perusahaan tektil yang terdaftar di BEI memiliki jumlah anggota komite audit paling sedikit 2orang dan paling banyak 4 orang. Nilai rata-rata sebesar 2.97 dengan standar deviasi 0.339. Hal ini menunjukkan bahwa data pada variabel ukuran komite audit memiliki sebaran yang kecil/berada di sekitar nilai rata-rata.
Tabel 2. Analisis Deskriptif Variabel Penelitian

\begin{tabular}{cccccc}
\hline & N & $\begin{array}{c}\text { Mini- } \\
\text { mum }\end{array}$ & $\begin{array}{c}\text { Maksi- } \\
\text { mum }\end{array}$ & Mean & $\begin{array}{c}\text { Std. } \\
\text { Deviation }\end{array}$ \\
\hline DA & 70 & -1.0899 & 1.0750 & -.011597 & 0.243031 \\
UKA & 70 & 2 & 4 & 2.97 & 0.339 \\
DKI & 70 & 0.0000 & 0.7500 & 0.385326 & 0.1199625 \\
KI & 70 & 0.0000 & 0.0000 & 0.672600 & 0.2014097 \\
KM & 70 & 0.0000 & 0.0829 & 0.009082 & 0.0213682 \\
FCF & 70 & -1.6956 & 3.6077 & 0.048118 & 0.5431761 \\
LEV & 70 & 0.1859 & 5.0252 & 1.133452 & 0.8885456 \\
ZISE & 70 & 23.3015 & 29.3263 & 27.255299 & 1.2079490 \\
\hline
\end{tabular}

Sumber: hasil pengolahan statistik

Variabel kontrol adalah ukuran perusahaan (SIZE), memiliki nilai minimum 23.3015 dan nilai maksimum 29.3263, serta rata-rata sebesar 27.255299 dengan standar deviasi 1.2079490 yang lebih kecil dari mean, hal ini berarti bahwa data ukuran perusahaan berada di sekitar nilai ratarata.

\section{Uji Asumsi Klasik}

Uji normalitas dilakukan dengan analisis penyebaran data pada grafik histogram dan normal probability plot. Pengujian normalitas juga dilakukan secara statistik untuk mendapatkan hasil yang lebih valid, yaitu dengan uji statistik non-parametrik Kolmogorov-Smirnov. Data dikatakan normal jika nilai signifikan lebih besar dari 0,05. Hasil pengujian statistik Kolmogorov Smirnov, bahwa data telah terdistribusi secara normal. Hal ini ditunjukkan oleh nilai signifikansi Kolmogorov-Smirnov yang berada di atas 0.05 yaitu sebesar 0.205. Selanjutnya, untuk mendukung hasil uji statistik tersebut, dilakukan pula uji normalitas melalui analisis grafik histogram dan normal probability plot. Setelah dilakukannya casewise diagnostics, model regresi telah terdistribusi secara normal. Hal ini ditunjukkan dari distribusi data yang membentuk seperti lonceng.

Pengujian terhadap adanya mulkolinieritas dalam penelitian ini adalah dengan menggunakan nilai tolerance dan variance inflation factor (VIF) pada model regresi. Jika tolerance value lebih dari 0,10 dan VIF kurang dari 10, hal ini menunjukkan bahwa tidak terjadi multikolienaritas. Nilai Durbin-Watson adalah sebesar 1.877. Hal ini berarti bahwa model regresi tidak mengindikasikan adanya autokorelasi karena nilai Durbin Watson (r) terletak pada batas antara du dan 4-du. Model regresi dalam penelitian ini bebas dari gejala heteroskedastisitas karena tidak ada pola tertentu pada grafik scatterplot tersebut. Titik-titik pada grafik relatif menyebar baik di atas sumbu Y maupun di bawah sumbu Y (tidak terdapat pola tertentu). 


\section{Pembuktian Hipotesis}

Analisis regresi linear berganda digunakan untuk mengukur pengaruh antara lebih dari satu variabel prediktor (variabel bebas) terhadap variabel terikat diperlihatkan seperti pada Tabel 3.

Tabel 3. Hasil Uji Statistik t

\begin{tabular}{cccc}
\hline Model & Koefisien & T & Sig. \\
\hline (Constant) & 2.711 & 3.977 & .000 \\
UKA & .040 & .448 & .656 \\
DK & -.204 & -.803 & .425 \\
KI & .085 & .553 & .582 \\
KM & -.124 & -.090 & .929 \\
FCF & -.477 & -2.724 & .009 \\
LEV & -.100 & -2.554 & .013 \\
SIZE & -.100 & -3.911 & .000 \\
\hline
\end{tabular}

Sumber: Hasil Pengolahan Dara

Berdasarkan hasil regresi linear berganda di atas, model persamaan regresi yang dihasilkan adalah:

$\mathrm{DA}=2.711-0.040 \mathrm{UKA}-0.204 \mathrm{DKI}+0.085 \mathrm{KI}-$ $0.124 \mathrm{KM}-0.477 \mathrm{FCF}-0.100 \mathrm{LEV}+0.100$ $\mathrm{SIZE}+\mathrm{e}$

Pada koefisien determinasi model regresi diperoleh nilai adjusted $R$ square sebesar 0.259. Hal ini berarti bahwa variabel independen ukuran komite audit, proporsi dewan komisaris independen, kepemilikan institusional, kepemilikan manajerial, free cash flow, dan leverage ratio, serta variabel kontrol ukuran perusahaan mampu menjelaskan perubahan variabel manajemen laba sebesar $25.9 \%$ sedangkan sisanya dipengaruhi oleh faktor lain yang tidak diteliti. Hasil uji statistik F ditunjukkan pada Tabel 4.

Tabel 4. Hasil Uji Statistik F

\begin{tabular}{llrrrrr}
\multicolumn{7}{c}{ ANOVA $^{\mathbf{b}}$} \\
\hline \multirow{2}{*}{ Model } & $\begin{array}{c}\text { Sum of } \\
\text { Squares }\end{array}$ & Df & $\begin{array}{c}\text { Mean } \\
\text { Square }\end{array}$ & F & Sig. \\
\hline 1 Regression & 1.047 & 8 & .131 & 2.636 & $.015^{\mathrm{a}}$ \\
Residual & 3.030 & 61 & .050 & & \\
Total & 4.078 & 69 & & & \\
\hline
\end{tabular}

a. Predictors: (Constant), LEV, FCF, DKI, UKA, KI, SIZE, KM

b. Dependent Variable: DA

Sumber : Hasil pengolahan data

Berdasarkan hasil uji statistik tersebut, diketahui nilai $\mathrm{F}$ sebesar 2.636 dengan tingkat signifikansi $0.015(<0.05)$ Hal ini berarti bahwa variabel independen yang terdiri dari ukuran komite audit, proporsi dewan komisaris independen, kepemilikan institusional, kepemilikan manajerial, free cash flow, dan leverage ratio, serta variabel kontrol ukuran perusahaan secara bersama-sama berpengaruh secara signifikan terhadap variabel dependen yakni praktik manajemen laba. Hal ini menunjukkan bahwa model regresi dalam penelitian ini benar-benar dapat diterima dan digunakan untuk memprediksi.

Hasil analisis regresi linear berganda dengan uji statistik t tersebut menunjukkan pengaruh dari masing-masing variabel independen terhadap variabel dependen. Variabel ukuran komite audit mempunyai nilai t sebesar 0.448 dengan tingkat signifikansi 0.656. Hal ini berarti bahwa tidak ada pengaruh signifikan ukuran komite audit terhadap manajemen laba, sehingga $\mathrm{H}_{1}$ ditolak.

Variabel proporsi dewan komisaris independen mempunyai nilai $t$ sebesar -0.803 dengan tingkat signifikansi 0.425 . Hal ini berarti bahwa tidak ada pengaruh signifikan proporsi dewan komisaris independen terhadap manajemen laba, sehingga $\mathrm{H}_{2}$ ditolak.Variabel kepemilikan institusional mempunyai nilai $\mathrm{t}$ sebesar 0.553 dengan tingkat signifikansi 0.582 . Hal ini berarti bahwa tingkat signifikansinya lebih besar daripada 0.05 , maka secara statistik pengaruhnya sangat kecil atau dikatakan bahwa tidak ada pengaruh signifikan kepemilikan institusional terhadap manajemen laba, sehingga $\mathrm{H}_{3}$ ditolak. Variabel kepemilikan manajerial mempunyai nilai t sebesar 0.090 dengan tingkat signifikansi 0.929 . Hal ini berarti bahwa kepemilikan manajerial berpengaruh negatif terhadap manajemen laba, tetapi karena tingkat signifikansinya lebih besar daripada 0.05 , maka secara statistik pengaruhnya sangat kecil atau bisa dikatakan bahwa tidak ada pengaruh kepemilikan manajerial terhadap manajemen laba, sehingga $\mathrm{H}_{4}$ ditolak.

Variabel free cash flow mempunyai nilai $\mathrm{t}$ sebesar -2.724 dengan tingkat signifikansi 0.009. Karena signifikansinya berada di bawah 0.05 hal ini berarti bahwa variabel free cash flow berpengaruh secara negatif signifikan terhadap manajemen laba sehingga $\mathrm{H}_{5}$ diterima. Variabel leverage ratio mempunyai nilai $\mathrm{t}$ sebesar -2.554 dengan tingkat signifikansi 0.013. Karena signifikansinya berada di bawah 0.05 hal ini berarti bahwa variabel free cash flow berpengaruh secara negatif signifikan terhadap manajemen laba sehingga $\mathrm{H}_{5}$ diterima.

\section{HASIL PENELITIAN DAN PEMBAHASAN}

\section{Pengaruh Ukuran Komite Audit terhadap Manajemen Laba}

Berdasarkan hasil analisis dapat disimpulkan bahwa ukuran komite audit tidak berpengaruh terhadap manajemen laba. Hasil penelitian ini 
juga konsisten dengan penelitian Alkdaei dan Hanefah (2012) yang menyimpulkan bahwa ukuran komite audit terbukti tidak berpengaruh terhadap manajemen laba.

Di Indonesia, terdapat peraturan Bapepam yang bersifat mandatory, sehingga tujuan perusahaan membentuk komite audit utamanya hanya untuk memenuhi sehingga terhindar dari sanksi hukuman. Oleh karena itu, kinerja dari komite audit kurang efektif dan optimal dalam mengembangkan dan menerapkan proses pengawasan untuk meminimalisir praktik manajemen laba. Menurut Effendi (2009:34), keberadaan komite audit di perusahaan publik sampai saat ini masih sekedar untuk memenuhi ketentuan pihak regulator (pemerintah) saja. Hal ini ditunjukkan dengan penunjukan anggota komite audit di perusahaan publik yang sebagian besar bukan didasarkan atas kompetensi dan kapabilitas yang memadai, namun lebih didasarkan pada kedekatan dengan dewan komisaris perusahaan. Anggota komite audit semacam ini sulit diharapkan untuk dapat bekerja secara profesional, sehingga besar kecilnya jumlah komite audit di perusahaan tidak akan bisa membatasi terjadinya praktik manajemen laba.

Hasil penelitian ini tidak mendukung penelitian Saleh et al. (2007) yang menjelaskan bahwa ukuran komite audit di sebuah perusahaan berpengaruh positif terhadap fungsi pengawasan dan kinerja komite, hal ini dikarenakan semakin banyak anggota komite audit maka semakin beragam pula keahlian dan pengetahuan dari masingmasing anggota yang bisa dimanfaatkan untuk mengembangkan dan menerapkan proses pengawasan dengan lebih efektif.

\section{Pengaruh Proporsi Dewan Komisaris Inde- penden terhadap Manajemen Laba}

Berdasarkan hasil analisis dapat disimpulkan bahwa proporsi dewan komisaris independen tidak berpengaruh terhadap manajemen laba. Hasil penelitian menunjukkan bahwa ukuran dewan komsiaris tidak memiliki kemampuan untuk mengendalikan pihak manajemen sehingga tidak dapat mengurangi earnings management. Hal ini dapat dijelaskan bahwa besar kecilnya dewan komisaris bukanlah menjadi faktor penentu utama dari efektivitas pengawasan terhadap manajemen perusahaan. Akan tetapi efektivitas mekanisme pengendalian tergantung pada nilai, norma dan kepercayaan yang diterima dalam suatu organisasi serta peran dewan komisaris dalam aktivitas pengendalian (monitoring) terhadap manajemen (Jennings, 2005).
Menurut Effendi (2009:20), dalam kaitannya dengan implementasi GCG di perusahaan, diharapkan bahwa keberadaan komisaris termasuk komisaris independen tidak hanya sebagai pelengkap, karena dalam diri komisaris melekat tanggung jawab secara hukum. Namun dalam praktik yang selama ini terjadi di Indonesia, terdapat kecenderungan bahwa kedudukan direksi biasanya sangat kuat, bahkan ada direksi yang enggan membagi wewenang serta tidak memberikan informasi yang memadai kepada komisaris independen. Selain itu, terdapat kendala yang cukup menghambat kinerja komisaris independen yaitu masih lemahnya kompetensi dan integritas mereka. Hal ini terjadi karena pengangkatan komisaris biasanya harus didasarkan pada penghargaan, hubungan keluarga, atau hubungan dekat lainnya, padahal integritas dan independensi merupakan hal yang fundamental agar GCG dalam perusahaan dapat terwujud secara efektif. Oleh karena itulah dewan komisaris independen di perusahaan masih belum bisa bekerja secara efektif dalam meningkatkan pengawasan terhadap operasional perusahaan dan terbukti tidak berpengaruh serta tidak bisa meminimalisir praktik manajemen laba.

Dewan komisaris independen tidak berpengaruh signifikan terhadap praktik manajemen laba, hal ini dikarenakan komisaris independen ditunjuk oleh pemegang saham mayoritas dalam RUPS sehingga apabila tidak sejalan dengan keputusan pemilik maka perusahaan dapat melakukan penggantian. Jadi, pada praktiknya meskipun komposisi dewan komisaris independen pada perusahaan relatif besar, tetapi mereka tidak bisa benar-benar independen dalam melaksanakan tugas dan pengawasannya karena terbatas oleh peraturan/kebijakan dari pemegang saham mayoritas, sehingga tidak bisa mendorong pelaksanaan good corporate governance secara optimal untuk membatasi praktik manajemen laba.

Semakin tinggi proporsi dewan komisaris, dapat menimbulkan agency problems (masalah keagenan), yaitu dengan makin banyaknya anggota dewan komisaris maka badan ini akan mengalami kesulitan dalam menjalankan perannya, diantaranya kesulitan dalam berkomunikasi dan mengkoordinir kerja dari masing-masing anggota dewan itu sendiri, kesulitan dalam mengawasi dan mengendalikan tindakan dari manajemen, serta kesulitan dalam mengambil keputusan yang berguna bagi perusahaan (Yermack, 1996) dan (Jensen, 1993). Adanya kesulitan dalam perusahaan dengan anggota dewan komisaris yang banyak ini membuat sulitnya menjalankan tugas pengawasan terhadap manajemen perusahaan yang nantinya berdampak pula pada 
kinerja perusahaan yang semakin menurun (Yermack 1996, Eisenberg et al. 1998). Zhou dan Chen (2004) menunjukkan bahwa ukuran dewan komisaris di bank komersial tidak berpengaruh terhadap earnings management yang diukur dengan menggunakan loan loss provisions. Hasil penelitian ini juga mendukung penelitian $\mathrm{Yu}$ (2006), Murhadi (2009); Oktovianti dan Agustia (2012). Hasil penelitian ini tidak mendukung penelitian dari Cornett et al. (2009) menemukan bahwa ukuran dewan komisaris berpengaruh negatif terhadap eranings management.

\section{Pengaruh Kepemilikan Institusional terhadap Manajemen Laba}

Berdasarkan hasil analisis dapat diketahui bahwa kepemilikan institusional tidak berpengaruh terhadap manajemen laba. Hasil penelitian ini mendukung penelitian Guna dan Herawaty (2010) dan Yang et al. (2009), Oktovianti dan Agustia (2012). Hasil penelitian ini menunjukkan bahwa kepemilikan institusional tidak memiliki kemampuan untuk mengendalikan pihak manajemen sehingga tidak dapat mengurangi earnings management. Kepemilikan saham yang besar tersebut seharusnya membuat investor institusional mempunyai kekuatan yang lebih dalam mengontrol kegiatan operasional perusahaan. Tetapi pada kenyataannya, kepemilikan institusional tidak bisa membatasi terjadinya manajemen laba. Hal ini dikarenakan investor institusional tidak berperan sebagai sophisticated investors yang memiliki lebih banyak kemampuan dan kesempatan untuk memonitor dan mendisiplinkan manajer agar lebih terfokus pada nilai perusahaan, serta membatasi kebijakan manajemen dalam melakukan manipulasi laba, melainkan berperan sebagai pemilik sementara yang lebih terfokus pada current earnings (Yang et al., 2009). Transient investors justru akan membuat pihak manajer mengambil kebijakan agar bisa mencapai target laba yang diinginkan para investor. Oleh karena itu, adanya kepemilikan institusional belum tentu akan berdampak pada peningkatan proses pengawasan yang berpengaruh terhadap berkurangnya tindakan manajemen dalam melakukan manajemen laba (Chew \& Gillan,2009:176). Hasil penelitian ini tidak konsisten dengan penelitian Cornett et al. (2006), yang hasilnya menunjukkan bahwa kepemilikan institusional dapat mengurangi tindakan earnings management.

\section{Pengaruh Kepemilikan Manajerial terhadap Manajemen Laba}

Berdasarkan hasil analisis dapat diketahui bahwa variabel kepemilikan manajerial tidak mempunyai pengaruh terhadap manajemen laba. Hasil penelitian ini konsisten dengan penelitian dari Guna dan Herawaty (2010) dan Pradipta (2011) yang juga menyimpulkan bahwa kepemilikan manajerial tidak bisa membatasi terjadinya manajemen laba.

Dari statistik deskriptif terlihat bahwa kepemilikan manajerial perusahaan di Indonesia sangat kecil dengan rata-rata di bawah $5 \%$. Sehingga para manajer yang juga memiliki saham perusahaan tersebut cenderung mengambil kebijakan untuk mengelola laba dengan sudut pandang keinginan investor, misalnya dengan meningkatkan laba yang dilaporkan sehingga banyak investor yang tertarik untuk menanamkan modal dan bisa menaikkan harga saham perusahaan. Kegagalan pihak manajemen yang juga merupakan pemilik modal perusahaan dalam meningkatkan kualitas dan proses pelaporan keuangan disebabkan karena presentase manajer yang memiliki saham relatif sangat kecil jika dibandingkan dengan keseluruhan modal yang dimiliki investor umum.

Hasil penelitian ini tidak mendukung penelitian Oktovianti dan Agustia (2012), yang menyatakan bahwa kepemilikan manajerial ini berpengaruh negatif signifikan terhadap earnings management. Weston dan Brigham (1994:17-23) menyatakan bahwa potensi munculnya konflik dalam hubungan agensi sangat besar, yaitu ketika manajemen perusahaan memiliki kurang dari $100 \%$ saham biasa milik perusahaan maka potensi konflik itupun muncul. Konflik terjadi karena adanya keinginan agen untuk mendapatkan gaji yang tinggi atau mendapatkan fasilitas tertentu yang sama dengan milik principal demi kenyamanan pribadinya.

\section{Pengaruh Free Cash Flow terhadap Mana- jemen Laba}

Berdasarkan hasil analisis dapat disimpulkan bahwa free cash flow berpengaruh negatif signifikan terhadap manajemen laba. White et al. (2003:68) mengungkapkan bahwa semakin besar free cash flow yang tersedia dalam suatu perusahaan, maka semakin sehat perusahaan tersebut karena memiliki kas yang tersedia untuk pertumbuhan, pembayaran hutang, dan deviden. Hal ini juga dapat diartikan bahwa semakin kecil nilai FCF yang dimiliki perusahaan, maka perusahaan tersebut bisa dikategorikan semakin tidak sehat.

Arus kas bebas (free cash flow) merupakan arus kas aktual yang bisa didistribusikan kepada investor sesudah perusahaan melakukan semua investasi dan modal kerja yang diperlukan untuk menjaga kelangsungan operasionalnya (Sawir, 
2004:93). Hasil penelitian ini konsisten dengan penelitian oleh Isnawati (2011) yang menyatakan bahwa FCF berpengaruh negatif signifikan terhadap manajemen laba. Pengaruh negatif tersebut dikarenakan free cash flow merupakan determinan penting dalam penentuan nilai perusahaan, sehingga manajer perusahaan lebih terfokus pada usaha untuk meningkatkan free cash flow.

Perusahaan dengan nilai free cash flow yang tinggi cenderung tidak akan melakukan manipulasi laba, karena dalam hal ini sebagian besar investor merupakan transient investors (pemilik sementara perusahaan) yang lebih terfokus pada informasi arus kas bebas perusahaan yang menunjukkan bagaimana kemampuan perusahaan dalam membagikan deviden, sehingga dengan arus kas bebas yang tinggi, tanpa adanya manajemen laba, perusahaan sudah bisa meningkatkan harga sahamnya karena investor melihat bahwa perusahaan tersebut mempunyai kelebihan kas untuk pembagian deviden (Mardiyanto, 2008:281).

\section{Leverage Ratio Berpengaruh terhadap Earn- ings Management (H2)}

Berdasarkan hasil analisis dapat disimpulkan bahwa leverage ratio berpengaruh signifikan terhadap manajemen laba. Hal ini mendukung hasil penelitian Mamedova (2008), Oktovianti dan Agustia (2012) yang menyatakan bahwa leverage perusahaan berpengaruh terhadap praktek manajemen melakukan earnings management. Perusahaan yang mempunyai rasio leverage yang tinggi, berarti proporsi hutangnya lebih tinggi dibandingkan dengan proporsi aktivanya akan cenderung melakukan manipulasi dalam bentuk earnings management sehingga perusahaan yang leveragenya tinggi cenderung mengatur laba yang dilaporkan dengan menaikkan atau menurunkan laba periode masa datang ke perioda saat ini.

Dalam teori keagenan, agen biasanya dianggap sebagai pihak yang ingin memaksimumkan dirinya tetapi ia tetap selalu berusaha memenuhi kontrak. Dalam hal kontrak utang, perusahaan merupakan agen dan kreditur sebagai prinsipal. Dengan begitu, perusahaan sebagai agen berkeinginan memaksimumkan dirinya tetapi ia tetap selalu berusaha memenuhi kontrak. Semakin dekat perusahaan dengan pelanggaran perjanjian utang yang berbasis akuntansi, lebih memungkinkan manajer perusahaan untuk memilih prosedur akuntansi yang memindahkan laba yang dilaporkan dari periode masa datang ke periode saat ini (Watts and Zimmerman, 1986).

Debt-covenant hypothesis menyatakan bahwa jika semua hal lain tetap sama, semakin dekat perusahaan dengan pelanggaran perjanjian utang yang berbasis akuntansi, lebih mungkin manajer perusahaan untuk memilih prosedur akuntansi yang memindahkan laba yang dilaporkan dari periode masa datang ke periode saat ini (Watts and Zimmerman, 1986). Hal tersebut dilakukan karena laba bersih yang dilaporkan naik akan mengurangi kemungkinan kegagalan membayar hutang-hutangnya pada masa mendatang (Scott, 2006:353). Jadi sangat dimungkinkan manajer perusahaan mempengaruhi angka-angka akuntansi pada laporan keuangan, khususnya angka laba bottom line.

\section{KESIMPULAN DAN SARAN}

\section{Kesimpulan}

Berdasarkan hasil analisis dan pembahasan pada bab sebelumnya, simpulan yang dapat diambil dari penelitian ini adalah sebagai berikut:

1. Variabel-variabel Good Corporate Governance (GCG) tidak berpengaruh terhadap praktek manajemen laba. Keberadaan komite audit dan proporsi dewan komisaris di perusahaan publik sampai saat ini masih sekedar untuk memenuhi ketentuan pihak regulator (pemerintah) saja, sehingga besar kecilnya jumlah komite audit dan proporsi dewan komisaris di perusahaan tidak bisa membatasi terjadinya praktik manajemen laba. Kepemilikan institusional tidak berpengaruh terhadap manajemen laba. Hal ini dikarenakan investor institusional tidak berperan sebagai sophisticated investors. Kepemilikan manajerial juga tidak berpengaruh terhadap manajemen laba karena presentase manajer yang memiliki saham relatif sangat kecil jika dibandingkan dengan keseluruhan modal yang dimiliki investor umum.

2. Variabel free cash flow berpengaruh negatif signifikan terhadap manajemen laba. Hal ini dikarenakan perusahaan dengan arus kas bebas yang tinggi cenderung tidak akan melakukan manajemen laba, karena meskipun tanpa adanya manajemen laba, perusahaan sudah bisa meningkatkan harga sahamnya.

3. Leverage ratio berpengaruh terhadap earnings management. Hasil ini menunjukkan bahwa perusahaan yang mempunyai rasio leverage yang tinggi, berarti proporsi hutangnya lebih tinggi dibandingkan dengan proporsi aktivanya akan cenderung melakukan manipulasi dalam bentuk manajemen laba.

\section{Keterbatasan Penelitian}

Berdasarkan hasil penelitian yang dilakukan, ada beberapa keterbatasan dalam penelitian ini, sebagai berikut: 
1. Perusahaan yang dipilih menjadi populasi dan sampel hanya dari perusahaan Textil yang ditentukan oleh peneliti dan tidak dapat dijadikan acuan untuk melakukan generalisasi pada seluruh perusahaan publik yang terdaftar di BEI.

2. Pengukuran variabel komite audit dan dewan komisaris dalam penelitian ini hanya menggunakan kuantitas keanggotaan (dilihat dari jumlah dan proporsi). Besaran jumlah tersebut mungkin belum cukup dalam merepresentasikan secara riil kinerja komite audit dan dewan komisaris di perusahaan. Selain itu, variabel independen hanya mampu menjelaskan 16.1\% dari variabel dependen, sedangkan sisanya dipengaruhi oleh variabel-variabel lain yang belum diteliti.

\section{Saran}

1. Untuk penelitian selanjutnya, disarankan mengambil sampel yang lebih luas misalnya dari semua sektor perusahaan yang terdaftar di BEI bukan hanya dari sektor perusahaan Tektil.

2. Prespektif earnings management yang digunakan dalam penelitian ini adalah prespektif oportunistis. Untuk penelitian selanjutnya earnings management perlu ditinjau dari prespektif yang lain, misalnya prespektif efisiensi yang menyatakan bahwa manajer melakukan pilihan atas kebijakan akuntansi untuk memberikan informasi yang lebih baik tentang cash flow yang akan datang.

3. Dalam penelitian selanjutnya, untuk variabel komite audit dan proporsi dewan komisaris independen dapat digunakan proksi lain yang lebih spesifik misalnya transparansi komite audit, jumlah pertemuan karakteristik dan kompetensi dewan komisaris independen.

\section{DAFTAR PUSTAKA}

Alkdai, H. and Hanefah, M. (2012). Audit committee characteristics and earnings management in Malaysian Shariah-compliant companies. Business and Management Review, 2(2), 5261.

Alves, Sandra Maria G. (2011). The Effect of the Board Structure on Earnings Management Evidence From Portugal. Journal of Financial Reporting and Accounting, 9(2), 141-160.

Badan Pusat Statistik. (2012). Indeks Produksi Industri Besar dan Sedang Menurut Dua Digit Kode ISIC, 2007-2011, Jakarta: Badan Pusat Statistik, http://www.bps.go.id/tab_sub/ view.php.
Bapepam. (2004). Peraturan IX.I.5. Pembentukan dan Pedoman Pelaksanaan Kerja Komite Audit. Jakarta: Badan Pengawas Pasar Modal.

Brigham, Eugene, F., and Houston, J. F. (2010). Dasar-dasar Manajemen Keuangan (Essential of Financial Management). Edisi ke sebelas, buku 1. Terjemahan oleh Ali Akbar Yulianto. Jakarta: Salemba Empat.

Bukit, R. B. and Iskandar, T. M. (2009). Surplus Free Cash Flow, Earnings Management and Audit Committee. Int. Journal of Economics and Management, 3(1), 204-223.

Chen, C. R. dan Steiner, T. L. (1999). Managerial Ownership and Agency Conflicts: A Nonliear Simultaneous Equation Analysis of Managerial Ownership, Risk Taking. Debt Policy, and Dividend Policy. The Financial Review. Tallahassee, 34(1), 119.

Chew, Donald, H., and Gillan, S. L. (2009). US Corporate Governance. Columbia: Columbia University Press.

Chung, R., Firth, M., and Kim, J. B. (2005). Earnings Management, Surplus Free Cash Flow, and External Monitoring. Journal of Business Research,58(6), 766-776.

Cornett, M. M., Marcus, A. J., and Tehranian, H. (2009). Corporate Governance And Earnings Management At Large U.S. Bank Holding Companies. Journal of Corporate Finance, 15, 412-430.

DeAngelo, H., DeAngelo, L., and Skinner. D. (1994). Accounting choice in troubled companies. Journal of Accounting and Economics, 17, 113-143.

Dechow, Patricia, M., Sloan, R.G., and Sweeney, A.P. (1996). Causes and Consequences of Earnings Manipulaton: An Analysis of Firms Subject to Enforcement Actions by the SEC. Contemporary Accounting Research, 13, 1-36.

Dewanto. (2012). Pengaruh Struktur Corporate Governance terhadap Manajemen Laba dan Nilai Perusahaan. Tesis tidak diterbitkan. Surabaya Universitas Airlangga.

Effendi, Arief. (2009). The Power of Good Corporate Governance Teori dan Implementasi. Jakarta: Salemba Empat.

Eisenberg, T., Sundgren, S., and Wells, M.T. (1998). Larger Board Size and Decreasing Firm Value in Small Firms. Journal of Financial Economics, 48, 35-54.

Eisenhardt, Kathleem, M. (1989). Agency Theory: An Assesment and Review. Academy of Management Review, 14, 57-74. 
Foster, George. (1986). Financial Statement Analysis, Second Edition, Englewood Cliffs, New Jersey: Prentice-Hall, A Division of Simon \& Schuster, Inc.

Fraser, Lyn, M., and Ormiston, A. (2004). Understanding Financial Statements. 7th edition. New Jersey: Preason edycation International, Inc., Upper Saddle River.

Ghozali, I. dan Chariri, A. (2007). Teori Akuntansi. Semarang: Badan Penerbit Universitas Diponegoro.

Gibson, Charles H. (2001). Financial Reporting and Analysis: Using Financial Accounting Information. United States of America: Southwestern college publishing.

Griffin, R. W. and Ebert, R. J. (2007). Business, Pearson International Edition. New Jersey: Prentice Hall.

Guna, W. I. and Herawaty, A. (2010). "Pengaruh Mekanisme Good Corporate Governance, Independensi Auditor, Kualitas Audit dan Faktor Lainnya Terhadap Manajemen Laba”. Jurnal Bisnis Dan Akuntansi. 12(1): 53-68.

Isnawati. (2011). Pengaruh Free Cash Flow Dan Growth Terhadap Manajemen Laba dengan Moderasi Komisaris Independen. Tesis tidak diterbitkan. Surabaya Universitas Airlangga.

Jennings, M. M. (Maret/April 2005). Conspicuous Governance Failures: Why Sarbanes-Oxley Is not an Ethics Warranty. Corporate Finance Review, 9(5), 41-47.

Jensen, M. C. (1993). The Modern Industrial Revolution, Exit, and The Failure of Internal Control Systems. The Journal of Finance, 48(3), 831-880.

Jensen, M. C. and Meckling, W.H. (1976). Theory of The Firm: Managerial Behavior, Agency Cost and Ownership Structure. Journal of Financial Economics, 3, 305-360.

Jones, Jenifer. (1991). Earning Management during Import Relief Investigation. Journal of Accounting Research Autumn, 193-228.

Kangarluei, S.J., Morteza, M., and Taher, A. (2011). The Investigation And Comparison Of Free Cash Flows In The Firms Listed In Tehran Stock Exchange (Tse) With An Emphasis On Earnings Management. Int. Journal of Economics and Business Modeling, 2(2), 118-1123.

Kouki, M., Abderrazek, E., Hanen, A., and Slim, S. (2011). Does Corporate Governance Constrain Earnings Management? Evidence from U.S. Firms. European Journal of Economics, $\mathrm{Fi}$ nance and Administrative Sciences, 35, 58-71.
Lin, J. W., Li, J. F., and Yang, J. S. (2006). The Effect Of Audit Committee Performance On Earnings Quality. Managerial Auditing Journal, 21(9), 921-933.

Mamedova, Irina Zagers. (2008). The Effect of Leverage Increases On Real Earnings Management. Thesis of Erasmus University in September 2008. http://publishing.eur.nl/ir/ repub/asset/15572/Accountability_zager.pdf

Mardiyanto, Handono. (2008). Inti Sari Manajemen Keuangan. Jakarta: Grasindo.

Murhadi, Werner R. (2009). Studi Pengaruh Good Corporate Governance Terhadap Praktik Earnings Management pada Perusahaan Terdaftar di PT Bursa Efek Indonesia. Jurnal Manajemen Dan Kewirausahaan, 11(1), 1-10.

Myers, S. C. and Nicholas, S. M. (1984). Corporate financing decisions when firms have investment information that investors do not. Journal of Financial Economics, 13(2), 187220.

Naz, I., Bhatti, K., Ghafoor, A., and Husein, H., (2011). Impact of Firm Size and Capital Structure on Earnings Management: Evidence from Pakistan. International Journal of Contemporary Business Studies, 2(12), 22-31.

National Committee on Corporate Governance (NCCG). (2001). Indonesian Code for Good Corporate Governance

Oktovianti, T. and Agustia, D. (2012). Influence of the Internal Corporate Governance and Leverage Ratio to the Earnings Management", Journal of Basic and Applied, 2(7), 7192-7199

Pradipta, Arya. (2011). Analisis Pengaruh dari Mekanisme Corporate Governance Terhadap Manajemen Laba. Jurnal Bisnis dan Akuntansi, 13(2), 93-106.

Saleh, N.M., Takiah, M.I., and Rahmat, M. (2007). Audit Committee Characteristics and Earnings Management: Evidence From Malaysia”. Asian Review of Accounting, 15(2), 147-163.

Sawir, Agnes. (2004). Kebijakan Pendanaan dan Restrukturisasi Perusahaan. Jakarta: PT. Gramedia Pustaka Utama.

Scott, William R. (2011). Financial Accounting Theory. Sixth Edition. Canada: Person Prentice Hall

Sekaran, Uma. (2007). Research Methods for Business. Jakarta: Penerbit Salemba Empat

Shleifer, A. and Vishny, R.W. (1997). A Survey of Corporate Governance. Journal of Finance, $52,737-783$. 
Sulistyanto, Sri H. (2008). Manajemen Laba: Teori dan Model Empiris. Jakarta: Grasindo.

Surya, I. dan Yustivandana, I. (2008). Penerapan Good Corporate Governance, Mengesampingkan Hak-Hak istimewa Demi Kelangsungan Usaha. Jakarta: Kencana Prenada Media Grup

Watts, R. L. and Zimmerman, J. L. (1986). Positive Accounting Theory, Engelwood Cliffs, NJ.

Weston, J. F. and Brigham, E. F. (1994). Essential of Managerial Finance. The Dryde Press-Harcourt Brace College Publishers.

Widyastuti, Tri. (2009). Pengaruh Struktur Kepemilikan dan Kinerja Keuangan Terhadap Manajemen Laba: Studi pada Perusahaan Manufaktur di BEI. Jurnal Maksi, 9(1), 30-41.
White, G. I., Sondhi, A. C., and Dov, F. (2003). The Analysis and Use Of Financial Statements. New York: John Wiley and Sons, Inc.

Yang, W. S., Loo, S. C., and Shamser. (2009). The Effect of Board Structure and Institutional Ownership Structure on Earnings Management. International Journal of Economics and Management, 3(2), 332-353.

Yermack, D. (1996). Higher Market Valuation of Companies with Small Board of Directors. Journal of Financial Economics. 40, 185-211.

Yu Frank. (2006). Corporate Governance and Earnings Management. Working Paper.

Zhou Jian and Chen Ken Y. (2004). Audit Committee, Board Characteristics and Earnings Management by Commercial Banks. Working Paper. http://aaahq.org/audit/midyear/05midyear/papers/ZHO_CG_EM_DEC16A. 